\title{
PROBLEM-BASED LEARNING IN A COLLEGE HISTORY CLASSROOM
}

\author{
L.M. Stallbaumer-Beishline \\ Bloomsburg University of Pennsylvania
}

\section{Introduction $^{1}$}

My traditional method of teaching, in lower or upper-level courses, had been to lecture and assign textbook chapters to read to establish context for discussion of primary and secondary sources related to a topic. Students seemed to enjoy my courses and I thought I was promoting active learning. Yet I came to realize that many students were not learning content, to read critically, or to contextualize the past. I began to doubt the effectiveness of my methods. My concerns increased one semester when I taught historiography. A struggling student came to me about two weeks before his big project was due and insisted that all he could see in a journal article was a series of facts and information; he did not find any interpretation, tone, or author's point of view. I read the article in front of him and identified point of view within the first paragraph. When he looked at me dumbfounded, I realized that he did not know how to hear voice in the text or to read between the lines. I judged that I had failed him, and he did fail the course. This combination of experiences led me on a search for answers to several questions: How do students develop historical cognition skills? How can we increase their engagement in the study of history? How do I teach students "to contextualize, corroborate, hear voice in text, and assess significance"'? ${ }^{2}$ My research and experience led me to conclude that (1) we need to teach history more consciously as a "thinking practice," "3 whatever the course topic, and (2) we should create doubt and uncertainty about the past through inquiry- or problem-based learning methods that can be adapted to history.

I do not claim to be the first historian to suggest this approach. Learning through discovery or inquiry is not new; its popularity has risen and fallen depending upon

${ }^{1}$ This paper was presented originally at the Biennial Phi Alpha Theta Convention, San Diego, January 2010.

\footnotetext{
${ }^{2}$ Robert Bain, "Into the Breach," in Knowing, Teaching, and Learning History: National and International Perspectives, eds. Peter N. Stearns, Peter Seixas, and Sam Wineburg (New York: New York University Press, 2001), 334.
}

${ }^{3}$ Sam Wineburg, Historical Thinking and Other Unnatural Acts (Philadelphia: Temple University Press, 2001), 78 . 
political and social developments over many decades. ${ }^{4}$ In some disciplines, this process is called Inquiry-Based (IBL) or Problem-Based Learning (PBL). The biggest difference between Inquiry and Problem-Based Learning appears to be the intensity and longevity of the experience. PBL might define the entire structure of the course, whereas Inquiry-Based Learning can be limited to class-length exercises. Curiously, advocates of PBL have been slow to understand how this method could be used to teach history, and I suspect that many historians are reluctant to contemplate PBL as a teaching method even though problematizing is at the heart of what we do.

\section{What is Problem-Based Learning?}

Problem-Based Learning refers to a specific kind of teaching method that is popular in medical schools. In PBL small groups of students work as teams to solve a problem and the instructor provides guidance. PBL does not begin with a textbook. Rather textbooks and other reference sources are consulted on a need-to-know basis. The problem should be open-ended and compel students "to make decisions based on facts, information, logic, and/or rationalization." The student groups define the problem with an instructor's help; in their teams, students brainstorm about the knowledge required to solve the problem, particularly what they do not know already; they research the problem and teach one another what they have learned; they summarize the results with the class and instructor; they apply what they know to the problem and identify gaps, or the instructor might add a new challenge to the problem; then the cycle resumes until they solve the problem.

There are three challenges to using the medical school model of PBL in a history class. First, can we create authentic experiences in the classroom? Second, can historical problems be open-ended? Third, is "problem-solving" what historians do?

\section{First challenge: Authenticity}

British history education specialist Chris Husbands argues that authenticity is difficult to meet because students are unlikely "to generate 'new' public knowledge from the study of (selected) historical evidence; they will generate new private

\footnotetext{
${ }^{4}$ Paul A. Kirschner, John Sweller, and Richard E. Clark, "Why Minimal Guidance During Instruction Does Not Work: An Analysis of the Failure of Constructivist, Discovery, Problem-Based, Experiential, and Inquiry-Based Teaching," Educational Psychologist, 41, 2 (2006), 75-86; Sigmund Tobia and Thomas M. Duffy, eds., Constructivist Instruction: Success or Failure? (London: Routledge, 2009).

${ }^{5}$ Barbara J. Duch, Deborah E. Allen, and Harold B. White III, "Problem-based Learning: Preparing Students to Succeed in the $21^{\text {st }}$ Century," Essays on Teaching Excellence: Toward the Best in the Academy, 9, 7 (1997-1998), n.p.
} 
understandings. ${ }^{96}$ Husbands correctly indicates the difficulty that students have in being original, by professional standards, at the undergraduate level. Research and writing courses offer the greatest potential for authentic experiences, but the majority of undergraduates will not go to the archives nor produce new public knowledge. What is more, in content-driven courses, most of us require students to examine the past through documents, but typically these are pre-selected and edited. Subsequently, students cannot get the "authentic" experience of searching through boxes of documents housed in archives or microfilmed on millions of frames.

Yet Husbands might dismiss too quickly the potential for authenticity when he writes, "Evidence has a place in historical work in the classroom not because it thereby makes classroom history 'authentic,' nor because it models the activity of the historian, but because of the sorts of thinking it supports and sorts of learning it makes possible."7 If inquiry into historical problems through documents, albeit pre-selected, is the central focus of our courses, enough authenticity is brought to the efforts to create meaningful experiences that replicate what it means to do history. We ask novice learners to apprentice what we do: Source documents, contextualize them, assess the significance of evidence, and make generalizations based upon the patterns that we find. That's doing history.

\section{Second challenge: Open-ended problems}

To an outsider, it might seem that history is not open-ended since we know the end of the story. But much of the past is open to debate because we never can be certain about what happened and how. In short, our understanding of the past is filled with uncertainty, and, according to Virginia Lee, "genuine uncertainty and doubt are the natural provocations for real learning." In my courses on Western Civilization, Total War Europe, Twentieth-Century Germany, and the Holocaust, we debate countless topics that historians problematize in order to generate dialogue and share results of research. Identifying problems is the starting point of our research and therefore inherently creates real-world and authentic experiences for students. Of

\footnotetext{
${ }^{6}$ Chris Husbands, What is History Teaching? Language, Ideas, and Meanings in Learning about the Past (Philadelphia: Open University Press, 2003), 26.

${ }^{7}$ Tbid.

${ }^{8}$ Virginia S. Lee, "The Uses of Uncertainty in the College Classroom," Teaching Excellence: Toward the Best in the Academy, http:/www.asa.mnscu.edu/facultydevelopment/resources/pod/Packet14/ theusesofuncertainty.htm (accessed on January 30, 2012).
} 
course, the problems we create by posing questions must be legitimate. ${ }^{9}$ In teaching the Holocaust, we should not ask why the Jews did not resist. It is not a legitimate question because it is based on a false premise that they did not. The more appropriate question of how Jews responded to persecution allows inquiry to proceed in a number of directions.

\section{Third challenge: Problem-solving}

For historians, to say that we want students to solve a problem is a misnomer. Historians rarely solve problems, given the degree of uncertainty for any past event. In reality, we offer plausible interpretations and ask students to do the same. Unfortunately, the process of arriving at a plausible interpretation does not lend itself to a catchy, concise phrase. Therefore, one solution might be to use the term InquiryBased Learning to describe the method of making problems our central focus, thus eliminating the misnomer.

\section{So, what problems can we create?}

The fact that we periodize the past is a source of controversy that generates problems worthy of investigation. The presentism inherent in periodizing has led to lively exchanges among historians about its accuracy and usefulness. In my survey class, students work with selected primary and secondary sources to answer an openended question: Which is more revolutionary, if at all: The Scientific Revolution, the Enlightenment, or the Industrial Revolution? In a course entitled Total War Europe, I ask students to consider whether or not the label "Total War Era" is the most effective and accurate way to understand European history from 1914 to 1945.

Several problems, posed in the form of questions, define content and assignments in my Holocaust course: Did the Nazis create a "racial state"? What were the origins of the "final solution"? Did the Nazis intend to kill Europe's Jews from the time Hitler came to power? Were the perpetrators "ordinary men"? What do we learn about human nature from perpetrators and victims of the Holocaust? Could Jews have been rescued during the Holocaust? Out of context, some of these questions might not appear problematical, but reading assignments, both primary and secondary, reveal to students that the answers are complex.

Problematizing the subject matter is just the beginning. We need to decide how to introduce a problem. Allow me to offer some ideas. First: According to the principles of Problem-Based Learning, we should not begin with a lecture or textbook reading. This starting point is based on a false assumption that students must master

\footnotetext{
${ }^{9}$ For a discussion of posing historical questions, see Patrick Rael, "What Happened and Why? Helping Students Read and Write Like Historians," The History Teacher, 39, 1 (November 2005), 23-25.
} 
factual knowledge before they can engage in higher-order thinking. Here, sophisticated research by cognitive psychologists reveals that complete factual mastery is not imperative to higher-order thinking. So, if the goal and content of a lecture is to disseminate factual information to create a foundation for critical thinking - that is facts must be mastered - we might not understand how learning occurs. Moreover, we might encourage unintentionally a belief that history is restricted to acquiring facts. Indeed, covering material in class does not guarantee that a student has learned. Who among us has not found essays and exams filled with factual errors even though we know we taught the material? Just because we covered it does not mean the students learned it. ${ }^{10}$

So should we never start a historical topic with lectures? It depends. I do introduce some topics with a lecture, but my lectures do not recount facts per se that students can read in a book. I create a classroom culture in which students understand that my lectures represent my expert opinion, a secondary source, on what happened and why. The lecture is driven by a thesis in the same way that we write journal articles for our peers. Of course, I encourage students to challenge my ideas as I lecture and when we hold discussions. In addition to framing the lecture as my personal journey of solving a historical problem, students know by way of the syllabus that they will explore course problems through formal and informal writing assignments. Lectures also can be used in the middle of an inquiry or problem to give students essential information when there is a need to know.

The PBL principle that textbooks should not be the starting point on a topic, but should only serve as a reference, is understandable. Sam Wineburg argues that textbooks remove doubt and give the illusion that "the way things are told is simply the ways things were." 11 If textbooks dominate the classroom, they encourage uncritical reading habits that make it more difficult for students to see history as a thinking practice. ${ }^{12}$ Yet textbooks can serve a useful function in an inquiry-driven history class. In my Holocaust course, I assign a readable history of the Holocaust by Doris Bergen that provides a master narrative and defines concepts and terminology that students

\footnotetext{
${ }^{10} \mathrm{James}$ Zull, The Art of Changing the Brain (Sterling, VA: Stylus, 2002), offers an informative, readable update on neuroscience research and its implications for teaching in higher education; Grant Wiggins and Jay McTighe, Understanding by Design (Alexandria, VA: ASCD, 1998), 106. Wiggins and McTighe have published an expanded second edition of Understanding by Design (Alexandria, VA: ASCD, 2005).

${ }^{11}$ Wineburg, Historical Thinking and Other Unnatural Acts, 12.

${ }^{12}$ Ibid., 78. For a discussion of U.S. history textbooks used in K-12, see the works of James Loewen, Lies My Teacher Told Me: Everything That Your American History Textbook Got Wrong (New York: New Press, 2008) and Teaching What Really Happened: How to Avoid the Tyranny of Textbooks and Get Students Excited about Doing History (New York: Teachers College Press, 2010).
} 
might reference since I do not always provide that information during lecture. ${ }^{13}$ When I teach a course on Hitler and the Third Reich, I use a textbook that offers a Hitlercentric interpretation as a counter-argument to my lectures. ${ }^{14}$ At the end of the semester, I ask students to write an essay that poses a problem: How important was Hitler to the Third Reich? In surveys, we can make the critique of problematic themes or interpretations in textbooks a central focus of a topic or even the entire course. Have students compare excerpts from textbooks written years apart. Then we can examine topics through additional primary and secondary sources. In short, textbooks can be used to create a problem in a way comparable to how medical schools pose problems in the form of case studies and to serve as a reference source.

Second: Begin a topic with a series of documents and ask students to interpret the evidence without benefit of lecture or textbook. I do this when examining the origins of the decision to kill European Jews. I assign students several documents to read and have them complete an informal writing assignment before coming to class. ${ }^{15}$ In theory, they have read the textbook assignment from Bergen. Only after discussion do I lecture to advance my own interpretation of decision-making between 1939 and 1941. The lecture then has more meaning to students because they have attempted to work with the documents on their own. Encouraging students to explore the documents without guidance from a text or lecture allows them to arrive at tentative conclusions and experience at a micro-level what historians do when we interpret the past from documents; they have to evaluate the reliability of documents, read between the lines of euphemistic language, and resolve contradictory evidence.

Third: Introduce a problem by exposing students to contrary interpretations; that is, introduce historiographical problems. Certain chapters from Donald Niewyk's The Holocaust (in Problems in European Civilization) are useful. ${ }^{16}$ For example, to examine the problem of Jewish resistance during the Holocaust, Raul Hilberg argues that Jews for the most part did not resist, while Yehuda Bauer says they engaged in numerous acts of resistance. These diametrically opposed interpretations allow students

\footnotetext{
${ }^{13}$ Doris Bergen, War and Genocide: A Concise History of the Holocaust, $2^{\text {nd }}$ ed. (London: Rowman \& Littlefield, 2009).

${ }^{14}$ Jackson J. Spielvogel, Hitler and Nazi Germany: A History, $5^{\text {th }}$ ed. (Upper Saddle River, NJ: Pearson Prentice Hall, 2005).

${ }^{15}$ The documents include Hitler's January 30, 1939, speech; Heydrich's September 21, 1939, directive on the creation of ghettos; the Foreign Ministry's Madagascar Plan of July 3, 1940; statements by Hans Frank in 1940 and 1941; Göring's directive to Heydrich, July 31, 1941; Einsatzgruppen reports from the fall of 1941; postwar Polish account of building at Belzec; and of course the Wannsee Conference Minutes.
}

${ }^{16}$ Donald Niewyk, The Holocaust: Problems and Perspectives of Interpretation, $3{ }^{\text {rd }}$ ed., Problems in European Civilization Series (Boston: Houghton Mifflin, 2003). 
to explore how working assumptions shape an historian's findings and create an opportunity to judge the plausibility of historical arguments. They then can examine the topic more thoroughly through primary sources and arrive at their own conclusions. Using historiographical problems to introduce a topic should not be reserved for upperlevel courses; there is no reason why students in college-level surveys cannot handle the challenge with guidance and abridged readings.

Fourth: Showing documentary films or just clips also can provide a way to introduce a problem. For example, The Road to Treblinka, in the series The Nazis: A Warning from History puts forth a functionalist interpretation of the origins of the decision to kill European Jews and contrasts effectively with assigned secondary sources. ${ }^{17}$ In teaching the origins of World War II recently, I started with a brief historiographic lecture and then showed the documentary The Wrong War, also part of The Nazis: A Warning from History, to initiate exploration of a problem: Did Hitler get the "wrong war" in either 1939 or 1941? After viewing and discussing the film, students explored the problem through primary sources to determine whether or not the film's thesis was plausible. I never assigned a textbook or alternative master narrative, which made me nervous until I saw the student essays. Their prior knowledge, a timeline that I provided, and some Internet exploration provided enough context to analyze the documents. Also important, when they constructed meaning from documents, they did history.

Fifth: Syllabi should describe themes or problems to explore. Routinely history syllabi list topics and eras to be covered in class. Instead, the topics should be introduced in the form of questions that emphasize problems to explore. The content section of my Holocaust syllabus is a list of questions as daily descriptions of what we will examine in class. Equally important, in the assignments section, we should state with clarity how we expect students to demonstrate understanding, e.g. formal and informal essays, reviews, discussion, etc. And at least we should indicate essay themes if not the actual questions. Objections might be raised that I "teach to the test" if I give students questions in advance. The criticism is understandable. But when "tests" are open-ended questions that ask students to draw upon lectures, discussions, documents, and historiography, then the test is worth teaching to. When we embark on a research project, do we not begin with a series of questions that we develop, refine, and define our focus.

How can we proceed to have students solve a problem or more accurately develop plausible interpretations? Many of us undoubtedly use the teaching methods that follow in this essay, but we bring new energy and direction to the classroom when we make inquiry the driving force in course design and choice of instructional method.

Organizing a class into groups or teams is a fundamental principle to ProblemBased Learning. In medical schools, groups routinely stay together for an entire

\footnotetext{
${ }^{17}$ The Nazis: A Warning from History is a BBC documentary released in the United States in 1998.
} 
semester. I believe that students learn effectively from one another when put into groups. I prefer to assign students to groups on an ad hoc basis rather than assign them to a group permanently. This is a personal preference. In essence, I do not allow the ideal model of PBL to prescribe how I teach.

Meaningful discussions are essential for PBL to work in a history class. The operative word here is meaningful: Discussions must be organized around exploring the problem(s). "Discussions" that test student abilities to recall details of a reading assignment can turn into a ping pong match between instructor and student. And the Socratic Method - or we might say Plato's method of posing a question to students as a springboard for an instructor's lecture-is not discussion. Starting discussion by assessing factual recall of readings to determine competency is based on the untested assumption that facts must be mastered before analysis can occur. More important, in discussion-method teaching, experience has taught me that students are likely to freeze up when you begin by asking questions that seek factual recall. They worry that they will fail to give the correct response and stay silent. Admittedly some reading assignments are more challenging than others, and in those cases I often start a discussion by pairing students up to discuss what confused them most about the source. Determining potential areas of misconceptions segue into analysis and exploration of facts. When students make assertions, we should demand that they support interpretations with facts. Students have an opportunity to share their interpretations with classmates, which recreates what historians do in colloquia and at conferences. More importantly, this allows students to test ideas with peers and it gives instructors an opportunity to identify misperceptions or errors in interpretation.

I often assign informal writing assignments that require students to think through material in advance of in-class work. When taken seriously and, of course, not all students do, students arrive to class prepared with questions and ideas to explore. Wikis and blogs might encourage an exchange of ideas outside of class as well. Informal writing assignments take less time to grade than formal essays as long as you avoid the urge to correct the writing line by line for grammar, punctuation, and syntax. ${ }^{18}$

Essay composition is popular in history courses, but we should frame essay questions as open-ended problems and require students to respond to a controversial interpretation or even counterfactual scenarios. This creates a need to develop an argument and reduces the chance that an essay reads like a history report, especially if

\footnotetext{
${ }^{18} \mathrm{John}$ Bean, Engaging Ideas: The Professor's Guide to Integrating Writing, Critical Thinking, and Active Learning in the Classroom (San Francisco: Jossey-Bass, 2001), 217-265, offers countless ideas on how to manage your grading time. See also Barbara E. Walvoord and Virginia Johnson Anderson, Effective Grading: A Tool for Learning and Assessment in College, $2^{\text {nd }}$ ed. (San Francisco: Jossey-Bass, 2010), 99-111, that provides useful tips as well.
} 
we make clear what the standards of proof are in historical research. ${ }^{19}$ In essence, I invite students as writers, not test-takers, to offer plausible interpretations of the sources given the problem, controversy, or mystery. If we pose the problem so that the audience is technically not the instructor, we increase the possibility that students will replicate what professionals do.

How we write assignments also can create real-world experiences for students: Develop a realistic scenario that requires a "solution." For example, I have students conduct a film analysis generated by a scenario where they have been approached to recommend films based upon their expertise on the Holocaust. In Total War Europe, I assigned a collection of essays called Twisted Paths that challenged "Total War" era periodization. ${ }^{20}$ In several classes, I have offered students an opportunity to engage in creative writing by hosting a panel discussion made up of historical figures; students must imagine how historical actors would respond to past situations or current events.

Finally, an essential means to encourage problem solving: We should introduce and develop in students an understanding of epistemological assumptions that shape our discipline, what might be referred to as decoding the discipline. ${ }^{21}$ This is not accomplished in one step at the beginning of the semesters but developed through our choice of readings, lectures, short exercises, and discussions. Denis Shemelt, a history educator in Great Britain, pointed out that historians ask students "to perform an unconscionable number of reverse somersaults." We tell them that no single correct answer exists, but some answers are simply wrong. We tell them that some answers are better than others, but there is no one best account. ${ }^{22}$ Why does our discipline generate so much ambiguity? We need to help students understand the way in which historical imagination handles the uncertainty of the past. We create order out of the chaos of the past which is what makes the study of history personally satisfying and worthwhile, in addition to providing a public service to contemporaries and posterity. Shemelt correctly notes that we should teach history as "a form of knowledge" that equips [students] to evaluate knowledge claims, to distinguish description from explanation,

\footnotetext{
${ }^{19}$ Stuart Green, "The Problem of Learning to Think Like a Historian," Educational Psychologist, 29, 2 (1994), 94-95. See also, John Bean, Engaging Ideas, 121-132; Walvoord and Anderson, Effective Grading, 20-11.
}

${ }^{20}$ Robert Gerwarth, ed., Twisted Paths: Europe, $1914-1945$ (Oxford: Oxford University Press, 2007).

${ }^{21}$ For a discussion specific to history, see Joan Middendorf and David Pace, "Decoding the Disciplines: A Model for Helping Students Learn Disciplinary Ways of Thinking," New Directions for Teaching and Learning, no. 98 (Summer 2004), 1-12.

${ }^{22}$ Denis Shemelt, "The Caliph's Coin," in Knowing, Teaching and Learning History, 98. 
and to debate the significance within historical narratives."23 What better way to accomplish this goal than by teaching history as problems to be explored.

\section{Conclusion}

Critics of problem-based learning point out that it works most effectively with intellectually mature students. Most students in surveys will struggle with PBL because they believe that they are empty vessels to be filled with knowledge which then is regurgitated in essays and exams. Many students just want to know what will be on an exam to get through the course. In response to the challenge of intellectual immaturity, the less intensive inquiry-based learning, which is essentially what I am proposing in this essay, can be done on a small-scale ad hoc basis. We can acculturate students to the idea that ultimately they are responsible for their learning and should make the most of their education. We must use our judgment to determine when students will need additional information, documentary evidence, or secondary sources to support them as they "do history." Then we might strike a more authentic balance between being the sage on the stage and the guide on the side.

We will increase the potential for student engagement in our courses if we teach history through inquiry-based methods that respond to open-ended questions that are meaningful and memorable. Equally important, instructors provide themselves with a clear purpose for designing or revising a course and its assignments if their starting point is to ask what problems we want students to explore, not what topics we need to cover. ${ }^{24}$ The content that we cherish in our subject matter is still being learned but given new meaning and relevance when we teach it in the context of a problem to solve.

${ }^{23} \mathrm{Ibid}$.

${ }^{24} \mathrm{On}$ the importance of designing a course around a clear purpose see Wiggins and McTighe, Understanding by Design, 159. While Wiggins and McTighe are more concerned with teaching at the $\mathrm{K}-12$ level, their book provides useful insight on how to design courses. An equally useful publication written specifically for higher education is L,. Dee Fink, Creating Significant Learning Experiences: An Integrated Approach to Designing College Courses (San Francisco: Jossey-Bass, 2003). 